\title{
Motivation, self-regulated learning, and their effects on learning outcomes of derivative materials during the Covid-19 pandemic
}

\author{
Analisa Fitria 1, a, *, Baiti Najihah", b, Muhammad Amin Paris 1, c, Muh. Fajaruddin Atsnan, d, \\ Maisea Ledua Nareki ${ }^{2, \mathrm{e}}$ \\ ${ }^{1}$ Department of Mathematics Education, Universitas Islam Negeri Banjarmasin \\ Jl. Ahmad Yani Km 4,5 Banjarmasin, South Kalimantan 70235, Indonesia \\ ${ }^{2}$ Mathematics Education and Physics, Gospel High School \\ Dhanji Street, Samabula, Suva 3384322, Fuji \\ E-mail: ${ }^{a}$ analisafitria@uin-antasari.ac.id, b baitinajihah@uin-antasari.ac.id, ${ }^{\mathrm{c}}$ m.aminparis@ $@$ uin-antasari.ac.id, \\ fajaratsnan@uin-antasari.ac.id, e maisealedua@gmail.com ${ }^{5}$ \\ * Corresponding Author
}

\begin{tabular}{|c|c|}
\hline ARTICLE INFO & ABSTRACT \\
\hline $\begin{array}{l}\text { Article history } \\
\text { Received: } 6 \text { Jul } 2021 \\
\text { Revised: } 19 \text { Nov } 2021 \\
\text { Accepted: } 29 \text { Nov } 2021\end{array}$ & $\begin{array}{l}\text { The study aims to identify the effect of learning motivation and self-regulated } \\
\text { learning on learning achievement in "Derivative" learning materials in } \\
\text { Trigonometry Functions. The study was field research using the ex-post facto } \\
\text { design and quantitative approach during the Covid-19 Pandemic. The } \\
\text { population was all grade XII students of a state Islamic senior high school in }\end{array}$ \\
\hline $\begin{array}{l}\text { Keywords } \\
\text { Covid-19 pandemi, learning } \\
\text { independence learning } \\
\text { motivation, learning } \\
\text { outcomes. }\end{array}$ & $\begin{array}{l}\text { South Kalimantan, Indonesia. The samples of } 24 \text { students were selected using } \\
\text { the purposive sampling technique. The data were gathered using a questionnaire } \\
\text { and test and through documentation and interview. The data were analysed } \\
\text { using the descriptive statistics and the inferential statistics consisting of } \\
\text { normality test, linearity test, multicollinearity test, heteroscedasticity test, and } \\
\text { multiple linear regression. The result shows that there is an effect of motivation }\end{array}$ \\
\hline Scan me: & $\begin{array}{l}\text { and learning independence during the Covid-19 pandemic, which contributed } \\
90.9 \% \text { in increasing mathematics learning outcomes, and the rest was affected } \\
\text { by other variables. This result is based on the results of } F \text {-test }\left(F_{\text {count }}=\right. \\
\left.104.948>F_{\text {table }}=3.47\right) \text { at the significance level of } 5 \% \text { with a multiple linear } \\
\text { regression model } \hat{Y}=13.557+0.435 X_{1}+0.395 X_{2}+\varepsilon \text {. }\end{array}$ \\
\hline
\end{tabular}

This is an open access article under the CC-BY-SA license.

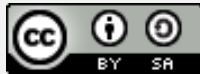

How to Cite: Fitria, A., Najihah, B., Paris, M. A., Atsnan, M. F., \& Nareki, M. L. (2021). Motivation, selfregulated learning, and their effects on learning outcomes of derivative materials during the Covid-19 pandemic. Jurnal Riset Pendidikan Matematika, 8(2), 153-166. https://doi.org/10.21831/jrpm.v8i2.42184

\section{INTRODUCTION}

The Covid-19 pandemic has impacted almost all over the world and various sectors, including education. Indonesia, as one of the affected countries, has made various policies to minimize the spread of the Covid-19 virus. One of the policies aimed to impose social restrictions (social distancing), which has great impact on various fields, especially education. The learning processes have to be conducted in online, which is previously accustomed to offline learning. This change in learning systems/models/methods have an impact on students' academic performance or learning outcome (Aguilera-Hermida, 2020, p.12). The changes in learning methods are suspected to decrease students' learning motivation and self-regulated learning (Cahyani, et.al, 2020, p.5).

Learning motivation and self-regulated learning are two important things in a learning process (Elliott, 2000, p.332) that determine students' learning outcome. Motivation is an important part that should be developed in every learning process that has been conducted (Nuriyatin \& Hartono, 2016, p.209). Learning motivation is a physical condition which encourages students to perform activities for attaining an objective namely good learning outcome (Fane \& Sugito, 2019, p.55). Through the 
existence of learning motivation, students are expected to be more active in attaining the expected learning outcome (Kurniawan \& Wustqa, 2014, p.179). Motivation is indeed one of the internal aspects that influence the achievement or the learning outcome of the students (Fane \& Sugito, 2019, p.55). At the same time, learning motivation is also one of the factors that determine the success of the students (Warmi, Adirakasiwi \& Santoso, 2020, p.198).

Similar situation also applies to self-regulated learning. Self regulated learning is a very important ability for students in learning process. Students who have Self-Regulated Learning will be able to plan goals, plan strategies, manage behaviors, and evaluate self-improvement (Fauzi \& Widjajanti, 2018, p.1). Students who have high sense of self-regulated learning, will develop sense of curiosity, will take active participation in learning process, will be able to think actively, will be able to think creatively, and will be able solve his or her own roblem (Azka \& Santoso, 2015, p.80). Students who are able to manage the self-regulated learning, will develop a positive attitude for attaining the learning success (Jatisunda, Nahdi \& Suciawati, 2020, pp.83-84). Thereby, self-regulated learning become one of the important aspects in learning process since it is able to impact the students' success in learning process (Zimmerman \& Schunk, 2011).

Mathematics is one of the domains in science that has significant role in both the school and the daily life (Gazali \& Atsnan, 2017, p.124). Due to its significant role, Mathematics has been considered as a branch of science that pays attention to the importance of balance. The intended balance is the importance of paying attention to the learning outcome that represent the cognitive aspects and also the attitudes that represent the affective aspects. In the learning process of Mathematics, there are many factors that influence such balance, including the students' personality (Purwanto et al., 2020, p.188). The students' success in learning Mathematics depends on their attitudes (Purwanto et al., 2020, p.2). When a student has positive attitude in the form of high motivation, then the student will be encouraged to gain better learning outcome of Mathematics (Rivai \& Murni, 2016, p.19). Indeed, learning motivation is in line with learning outcome of the students.

Another aspect that should be given attention in learning process is self-regulated learning (Qohar \& Sumarmo, 2013, p.61). There are three characteristics of self-regulated learning namely planning learning independently, implementing learning independently, and evaluating learning outcome independently (Zimmerman, 2001). In the context of Mathematics learning process, students are expected to be active and independent during the learning process so that they will eventually be able to solve the mathematical test items (Kurniyawati, Mahmudi \& Wahyuningrum, 2019, p.120). Students who have independency within the learning process will not depend on the assistance by the teachers throughout the learning process.

When Covid-19 pandemics have overwhelmed, including Indonesia, most of the activities in education, including study and learning process, should be conducted online. As a consequence, many students benefit numerous platforms of technology for learning from home (Wijaya, Ying \& Suan, 2020, p.726). Ironically, as the students learn from home, they should deal with so many temptations that might make them lazy, whereas they should have learning motivation and self-regulated learning due to the minimum or the limited interaction between the teachers and the students (Lestari, Aisah \& Nurafifah, 2020, p.2; Ambiyar, Aziz \& Melisa, 2020, p.1246). This situation becomes more complex since Mathematics has been one of the most difficult lesson to understand through the online learning process. The reason is that many teachers of Mathematics have low adaptive capacity; in other words, these teachers are not ready to teach Mathematics online (Atmojo, Muhtarom \& Lukitoaji, 2020, p.513). In the normal situation, learning motivation and self-regulated learning influence the students' learning outcome in Mathematics. This article discuss the impact of the two aspect during the Covid-19 pandemic, particulary focus on two research questions: Do the two aspects influence the learning outcome in mathematics during Covid-19 Pandemics? In addition, how are the students' learning motivation and self-regulated learning during Covid-19 Pandemics?

Previous relevant research from Siregar \& Manurung (2021), states that the Covid-19 pandemic has made the learning system from offline to online, which has an impact on his motivation to learn mathematics. Meanwhile, research from Nurhayati \& Purwanto (2021), also stated that some research samples in class XI Science still had good motivation in learning mathematics even in the Covid-19 pandemic situation. Meanwhile, Mou's research (2021) states that the Covid-19 pandemic has weakened the independence of learning mathematics. Therefore, this study also wants to find out how students' 
motivation and independence in learning mathematics during the Covid-19 pandemic are, particularly on derivative material.

\section{METHOD}

The researcher implemented the Ex-Post Facto design using the quantitative approach (Sugiyono, 2016, p.14). The independent variables in the study were learning motivation and self-regulated learning during Covid-19 pandemic on materials of Derivative in Trigonometry Function. The dependent variable was learning outcome given materials. The population in the study was 112 Grade XII students a state Islamic senior high school in South Kalimantan, Indonesia Academic Year 2020/2021, which had been divided into four parallel classrooms. The details on the composition were provided in Table 1 .

Table 1. Research population

\begin{tabular}{lc}
\hline Grade & Total \\
\hline XII Natural Science 1 & 24 \\
XII Natural Science 2 & 28 \\
XII Social Science 1 & 31 \\
XII Social Science 2 & 29 \\
Total & 112 \\
\hline
\end{tabular}

Then, the samples that had been selected as the subjects in the study were the students from Grade XII Natural Science 1 at the school. These samples were selected by using purposive sampling technique based on the consideration and the policy of the school principal and the willingness of the Mathematics teacher for the given class. In addition, the purposive sampling technique was implemented because Grade XII had been the only grade that implemented Google Classroom as the learning media for Mathematics.

Next, the data in the study were gathered using questionnaire distribution, test, documentation, and interview. The questionnaire was distributed in order to measure the learning motivation and the self-regulated learning of the students. Following the questionnaire, the test was administered in order to gather the data on the learning outcome of Mathematics from the students. Afterward, the documentation was implemented in order to attain the general description of the research site, namely the data of teachers, educational personel, students, learning outcome, and facilities.

The guidelines of the motivation questionnaire were based on the indicators that had been adopted from Lestari \& Yudhanegara (2017, p.181). These guidelines were presented in Table 2.

Table 2. Guidelines of learning motivation questionnaire

\begin{tabular}{cllc}
\hline No & Indicators & Number of Item & Total \\
\hline 1 & Showing learning needs and encouragement & $1,2,3,4,5,6$ & 6 \\
2 & Showing interest and enthusiasm in the given & $7,8,9.10,11,12$ & 6 \\
3 & assignments & $13,14,15,16,17,18$ & 6 \\
4 & Being persistent in dealing with assignments & $19,20,21$ & 3 \\
5 & Showing passion and desire for success & $21,22,23,24$ & 4 \\
\hline
\end{tabular}

In relation to the learning motivation questionnaire, the criteria on learning motivation interpretation were adopted from Arikunto (2010, p.196). These criteria were presented in Table 3.

Table 3. Criteria on learning motivation interpretation

\begin{tabular}{cll}
\hline No & Percentage & Interpretation \\
\hline 1 & $81 \%-100 \%$ & Very good \\
2 & $61 \%-80 \%$ & Good \\
3 & $41 \%-60 \%$ & Moderate \\
4 & $21 \%-40 \%$ & Poor \\
5 & $0 \%-20 \%$ & Very poor \\
\hline
\end{tabular}


Jurnal Riset Pendidikan Matematika, 8 (2), 2021 - 156

Analisa Fitria, Baiti Najihah, Muhammad Amin Paris, Muh. Fajaruddin Atsnan, Maisea Ledua Nareki

On the other hand, the guidelines on the self-regulated learning were based on the indicators by Wahyuningsih (2020, p.187). These guidelines were presented in Table 4.

Table 4. Guidelines on self-regulated learning questionnaire

\begin{tabular}{|c|c|c|c|}
\hline No & Indicators & Number of Item & Total \\
\hline 1 & Having initiative to plan learning strategy & $1,2,3,4,5,6,7,8$ & 8 \\
\hline 2 & Regulating and directive oneself to learn & $9,10,11,12,13,14,15$ & 7 \\
\hline 3 & $\begin{array}{l}\text { Not being dependent on others in implementing } \\
\text { learning strategy }\end{array}$ & $16,17,18,19,20$ & 5 \\
\hline 4 & Being responsible to oneself in learning & $21,22,23,24,25$ & 5 \\
\hline
\end{tabular}

In relation to the self-regulated learning questionnaire, the criteria on self-regulated learning interpretation were adopted from Ridwan \& Sunarto (2009, p.23). These criteria were presented in Table 5.

Table 5. Criteria on self-regulated learning interpretation

\begin{tabular}{cll}
\hline No & Mean Percentage & Interpretation \\
\hline 1 & $0 \%-19,99 \%$ & Poorly self-regulated \\
2 & $20 \%-39,99 \%$ & Less self-regulated \\
3 & $40 \%-59,99 \%$ & Moderately self-regulated \\
4 & $60 \%-79,99 \%$ & Self-regulated \\
5 & $80 \%-100 \%$ & Highly self-regulated \\
\hline
\end{tabular}

Eventually, the test that had been administered in the study consisted of 21 items that contained the indicators of learning motivation and self-regulated learning. The two sets of questionnaires had been validated by expert and were experimented again to the students of Grade XII Natural Science 2. In conducting the study, only reliable items were selected. Based on the SPSS output, it was found that for the learning motivation questionnaire the Cronbach's Alpha value had been 0.905. Compared to $r_{\text {table }}$ with $N=28$ at rate of significance $5 \%$, the $r_{\text {table }}=0.374$. Since $0.905>0.374$, it could be concluded that the learning motivation questionnaire had been reliable. On the other hand, it was also found that for the self-regulated learning motivation question the Cronbach's Alpha value had been 0.892 . In relation to the $r_{\text {table }}$ value, it was clear that $0.892>0.374$. Therefore, it could also be concluded that the self-regulated learning questionnaire had been reliable. Furthermore, after all of the data had been gathered, the data were analysed using questionnaire data analysis technique, learning outcome data analysis technique, descriptive statistics technique, and inferential statistics technique. The inferential statistics techniques itself consisted of prerequisite test, which covered normality test, linearity test, multicollinearity test, heteroscedasticity test, and multiple linear regression analysis. In order to identify the model fitness within the multiple linear regression, multiple linear regression analysis, coefficient of determination analysis, t-test, and F-test should be conducted.

\section{RESULT AND DISSCUSSION}

\section{Learning motivation questionnaire analysis}

The data on the learning motivation have been attained from a questionnaire set that consists of 19 items. The mean percentage of each indicator is available in Table 6.

Table 6. Mean percentage of each indicator for learning motivation from grade XII natural science 1 students

\begin{tabular}{lc}
\hline Learning motivation indicators & Percentage \\
\hline Showing learning needs and encouragement & $52.32 \%$ \\
Showing interest and enthusiasm in the given assignments & $52.57 \%$ \\
Being persistent in dealing with assignments & $46.04 \%$ \\
Being diligent in dealing with difficulties & $47.68 \%$ \\
Showing passion and desire for success & $42.25 \%$ \\
\hline
\end{tabular}


Based on the results in Table 6 , for the first indicator - showing learning needs and encouragement, the mean percentage of learning motivation among Grade XII Natural Science 1 students is $52.32 \%$, which belongs to the "Moderate" category. This percentage implies that most of the students have encouragement in learning Mathematics and they do really like the lesson because they think that they have the needs to learn it. Then, for the second indicator - showing interest and enthusiasm in the given assignments, the mean percentage is $52.57 \%$, which still belongs to the "Moderate" category. The reason is that half of the students are unwilling to ask the learning materials that they have not understood. In addition, the students only retrieve what the teachers have explained and they do not try to find for other learning resources.

The third indicator - being persistent in dealing with assignments, reach $46.04 \%$ which is in "Moderate" category. The reason is that most of the students still procrastinate or did not pay attention to the assignments that the teachers have assigned. Furthermore, for the fourth indicator - being diligent in dealing with difficulties, the mean percentage is $47.68 \%$, which belongs to the "Moderate" category. The reason is that most of the students are less striving in completing their test items and improving their scores. At the same time, they easily give up when they deal with difficult test items. Last but not the least, for the fifth indicator - showing passion and desire for success, the mean percentage is $42.25 \%$, which belongs to the "Moderate" category. This finding shows that more than half of the students have the willingness to understand Mathematics and attain the desired results.

\section{Self-Regulated learning analysis}

Students' self-regulated learning data have been attained from a questionnaire that consists of 23 items. The mean percentage of each indicator is available in Table 7.

Table 7. Mean percentage on each indicator of self-regulated learning from grade XII natural science 1 students

\begin{tabular}{lc}
\hline Self-regulated learning indicators & Percentage \\
\hline Having initiative to plan learning strategy & $42.67 \%$ \\
Regulating and directive oneself to learn & $46.68 \%$ \\
Not being dependent on others in implementing learning strategy & $41.44 \%$ \\
Being responsible to oneself in learning & $47.71 \%$ \\
\hline
\end{tabular}

Based on the results in Table 7, the mean percentage of the first indicator - having initiative to plan learning strategy, is $42.67 \%$, which belongs to "Moderately Self-Regulated" category. This finding is marked by the fact that half of the students have prepared themselves to learn Mathematics, starting from making learning schedule down to learning materials prior to the class and eventually opening themselves to the learning method update. The second indicator - regulating and directive oneself to learn, reachs $46.68 \%$, which belongs to the "Moderately Self-Regulated" category. This finding shows that almost half of the students direct themselves to use the learning methods that they prefer, encourage themselves to share their opinion, identify their weaknesses and their errors in learning Mathematics, and improving their performance in Mathematics. Next, the third indicator - not being dependent on others in implementing learning strategy, has the mean percentage was $41.44 \%$, which belongs to the "Moderately Self-Regulated" category. The reason is that most of the students are less able to understand and complete the mathematical test items and that they decide to be dependent on other people. Last but not the least, the fourth indicator - being responsible to oneself in learning, has $47.71 \%$ in "Moderately Self-Regulated" category. The reason is that most of the students are less confident with their understanding and self-performance in learning Mathematics; therefore, they become less responsible with themselves.

\section{Mathematics learning outcome analysis}

The learning outcome of Mathematics have been attained from the daily examination score on materials of "Derivatives" from Trigonometry Functions. The data that have been attained are tabulated into the table of frequency distribution. The mean of the data $(\bar{x})$ is 80.29 and its standard deviation $(S D)$ is 6.91. The students' Mathematics learning outcome are summarized in Figure 1. 


\section{Mathematics Learning Results of Grade XII Natural Science 1 Students}

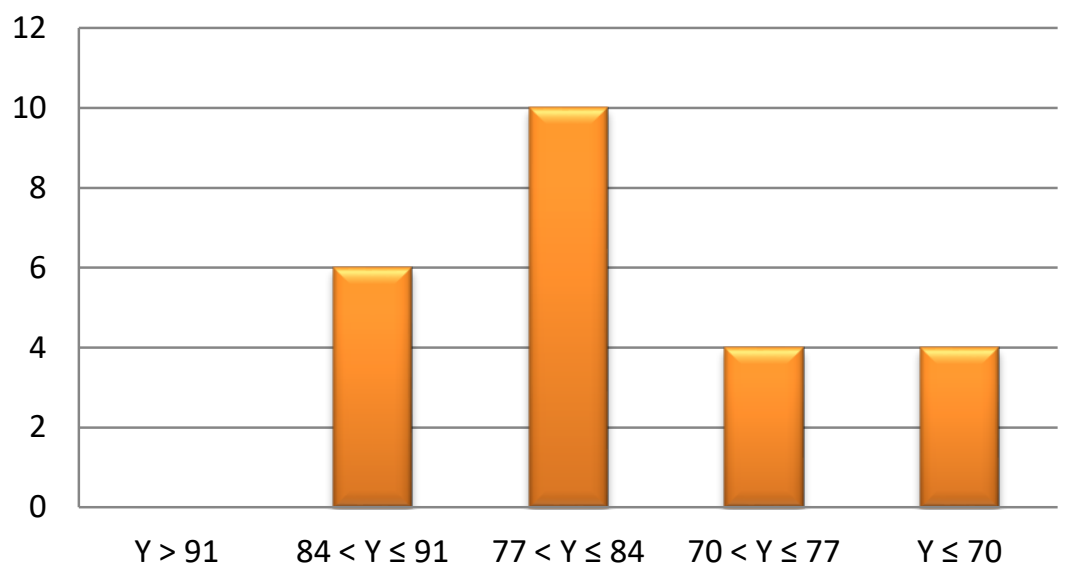

Figure 1. Data on mathematics learning outcome

Based on the results in Figure 1, it is clear that the Mathematics learning outcome of Grade XII Science 1 students from a state Islamic senior high school in South Kalimantan, Indonesia can be described as follows: 6 students belong to "High" category, 10 students belong to "Moderate" category, and 4 students belong to "Low" and "Very Low" category.

\section{Statistical test}

\section{Classical assumption test}

The classical assumption test was conducted prior to multiple linear regression analysis, which consisted of normality test, linearity test, multicollinearity test, and heteroscedasticity test.

\section{Normality test}

The normality test was conducted in order to identify the data normality distribution. In this study, the normality test was conducted using Kolmogorov-Smirnov Method. Table 8 shows the result of learning motivation normality test.

Table 8. Learning motivation normality test

\begin{tabular}{lcccccc}
\hline \multicolumn{7}{c}{ Tests of Normality } \\
\hline & \multicolumn{3}{c}{ Kolmogorov-Smirnov ${ }^{\text {a }}$} & \multicolumn{3}{c}{ Shapiro-Wilk } \\
\cline { 2 - 8 } & Statistic & $d f$ & Sig. & Statistic & $d f$ & Sig. \\
\hline $\begin{array}{l}\text { Learning motivation } \\
\text { *. This is a lower bound of the true significance. } \\
\text { a. Lilliefors Significance Correction }\end{array}$ & 0.123 & 24 & $0.200^{*}$ & 0.945 & 24 & 0.207 \\
\hline
\end{tabular}

Based on the SPSS output in Table 8, it shows that significance value of Kolmogorov Smirnov is 0.200 . This value is higher than 0.050 (sig. > 0.050). Therefore, it can be concluded that the data is normally distributed. Table 9 presents the result of self-regulated learning normality test.

Table 9. Self-regulated learning normality test

\begin{tabular}{lcccccc}
\hline & \multicolumn{3}{c}{ Tests of Normality } \\
\hline & \multicolumn{4}{c}{ Kolmogorov-Smirnov ${ }^{\text {a }}$} & \multicolumn{3}{c}{ Shapiro-Wilk } \\
\cline { 2 - 7 } & Statistic & $d f$ & Sig. & Statistic & $d f$ & Sig. \\
\hline $\begin{array}{l}\text { Self-regulated learning } \\
\text { a. Lilliefors Significance Correction }\end{array}$ & 0.173 & 24 & 0.063 & 0.858 & 24 & 0.003 \\
\hline
\end{tabular}


Jurnal Riset Pendidikan Matematika, 8 (2), 2021 - 159

Analisa Fitria, Baiti Najihah, Muhammad Amin Paris, Muh. Fajaruddin Atsnan, Maisea Ledua Nareki

Based on the SPSS output in Table 9, it shows that significance value of Kolmogorov Smirnov is 0.063. This value is higher than 0.050 ( $\mathrm{sig}$. $>0.050$ ). Therefore, it can be concluded that the data is normally distributed.

Table 10. Learning outcome normality test

\begin{tabular}{|c|c|c|c|c|c|c|}
\hline \multicolumn{7}{|c|}{ Tests of Normality } \\
\hline & \multicolumn{3}{|c|}{ Kolmogorov-Smirnov ${ }^{\mathrm{a}}$} & \multicolumn{3}{|c|}{ Shapiro-Wilk } \\
\hline & Statistic & $d f$ & Sig. & Statistic & $d f$ & Sig. \\
\hline $\begin{array}{l}\text { Mathematics learning outcome } \\
\text { *. This is a lower bound of the true significance. } \\
\text { a. Lilliefors Significance Correction }\end{array}$ & 0.130 & 24 & $0.200^{*}$ & 0.931 & 24 & 0.101 \\
\hline
\end{tabular}

Based on the SPSS output in Table 10, it shows that significance value of Kolmogorov Smirnov is 0.200 . This value is higher than 0.050 ( $\mathrm{sig}$. > 0.050). Therefore, it can be concluded that the data is normally distributed.

\section{Linearity test}

The linearity test was conducted in order to identify whether the data had been in accordance with the linear line or not.

Table 11. Linearity test of learning motivation and mathematics learning outcome

\begin{tabular}{|c|c|c|c|c|c|c|c|}
\hline \multicolumn{8}{|c|}{ ANOVA Table } \\
\hline & & & $\begin{array}{l}\text { Sum of } \\
\text { Squares }\end{array}$ & $d f$ & $\begin{array}{c}\text { Mean } \\
\text { Square }\end{array}$ & $F$ & Sig. \\
\hline \multirow{6}{*}{$\begin{array}{l}\text { Mathematics } \\
\text { Learning } \\
\text { outcome*Learning } \\
\text { Motivation }\end{array}$} & & (Combined) & 1152.258 & 13 & 88.635 & 15.186 & 0.000 \\
\hline & & Linearity & 1029.092 & 1 & 1029.092 & 176.315 & 0.000 \\
\hline & Between groups & Deviation & & & & & \\
\hline & & from & 123.166 & 12 & 10.264 & 1.759 & 0.190 \\
\hline & Within groups & & 58.367 & 10 & 5.837 & & \\
\hline & Total & & 1210.625 & 23 & & & \\
\hline
\end{tabular}

Based on the SPSS output in Table 11, it implies that Deviation from Linearity had been 0.190. Since this value is higher than 0.050 , it can be concluded that the relationship between learning motivation $\left(\mathrm{X}_{1}\right)$ and Mathematics learning outcome $(\mathrm{Y})$ is linear.

Table 12. Linearity test of self-regulated learning and mathematics learning outcome

\begin{tabular}{|c|c|c|c|c|c|c|c|}
\hline \multicolumn{8}{|c|}{ ANOVA Table } \\
\hline & & & $\begin{array}{l}\text { Sum of } \\
\text { Squares }\end{array}$ & $d f$ & $\begin{array}{l}\text { Mean } \\
\text { Square }\end{array}$ & $F$ & Sig. \\
\hline \multirow{5}{*}{$\begin{array}{l}\text { Mathematics } \\
\text { Learning } \\
\text { outcome*Self- } \\
\text { Regulated } \\
\text { Learning }\end{array}$} & & (Combined) & 1156.458 & 12 & 96.372 & 19.571 & 0.000 \\
\hline & Between & Linearity & 1021.537 & 1 & 1021.537 & 207.451 & 0.000 \\
\hline & groups & $\begin{array}{l}\text { Deviation from } \\
\text { linearity }\end{array}$ & 134.922 & 11 & 12.266 & 2.491 & 0.073 \\
\hline & Within groups & & 54.167 & 11 & 4.924 & & \\
\hline & Total & & 1210.625 & 23 & & & \\
\hline
\end{tabular}

Based on the SPSS output in Table 12, it shows that Deviation from Linearity is 0.073. Since this value is higher than 0.050 , it can be concluded that the relationship between self-regulated learning $\left(\mathrm{X}_{2}\right)$ and Mathematics learning outcome $(\mathrm{Y})$ is linear.

\section{Multicollinearity test}

Multicollinearity test was conducted in order to identify whether the independent variables had inter-variable similarity in a model or not. At the same time, this test was conducted in order to avoid 
Jurnal Riset Pendidikan Matematika, 8 (2), 2021 - 160

Analisa Fitria, Baiti Najihah, Muhammad Amin Paris, Muh. Fajaruddin Atsnan, Maisea Ledua Nareki

the habituation in the decision-making process with regards to the influence on the partial test of the independent variable on the dependent variable.

Table 13. Multicollinearity test

\begin{tabular}{|c|c|c|c|c|c|c|c|}
\hline \multicolumn{8}{|c|}{ Coefficients $^{\mathrm{a}}$} \\
\hline \multirow[t]{2}{*}{ Model } & \multicolumn{2}{|c|}{$\begin{array}{l}\text { Unstandardized } \\
\text { Coefficients }\end{array}$} & \multirow{2}{*}{$\begin{array}{c}\begin{array}{c}\text { Standardized } \\
\text { Coefficients }\end{array} \\
\text { Beta } \\
\end{array}$} & \multirow[t]{2}{*}{$t$} & \multirow[t]{2}{*}{ Sig. } & \multicolumn{2}{|c|}{ Collinearity Statistics } \\
\hline & $B$ & Std. Error & & & & Tolerance & VIF \\
\hline (Constant) & 13.557 & 4.681 & & 2.896 & 0.009 & & \\
\hline${ }_{1}$ Learning motivation & 0.453 & 0.117 & 0.506 & 3.881 & 0.001 & .255 & 3.929 \\
\hline Self-regulated learning & 0.395 & 0.107 & 0.481 & 3.691 & 0.001 & 0.255 & 3.929 \\
\hline
\end{tabular}

Based on the SPSS output in Table 13, it shows that VIF value is 3.929. Since this value is within the range of 1-10, it can be concluded that multicollinearity do not take place.

\section{Heteroscedasticity Test}

Heteroscedasticity test was conducted in order to test the difference on the residual variance from one single period of observation to another. Within the study, the heteroscedasticity test was conducted by using Scatterplot.

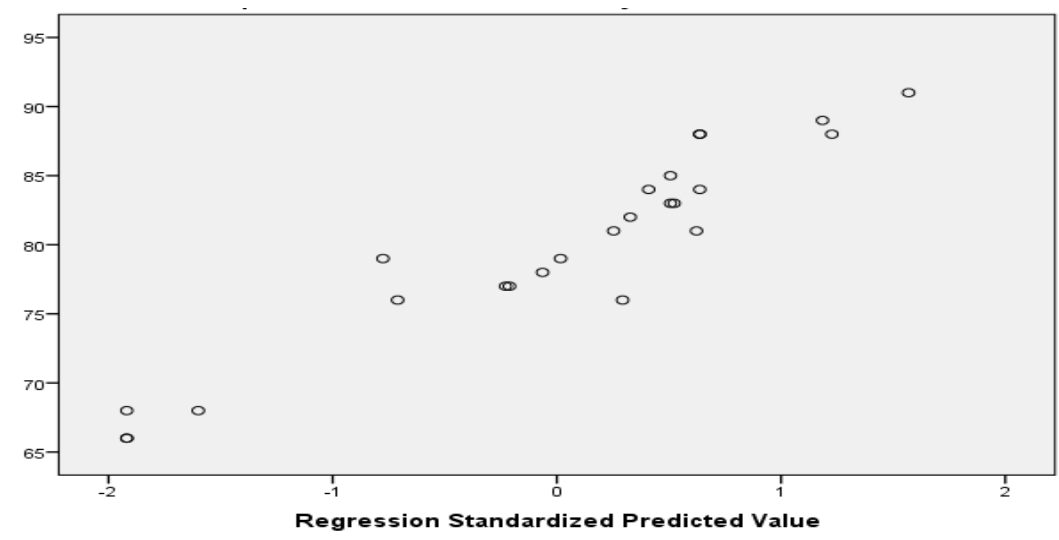

Figure 2. Scatterplot of heteroscedasticity test results

Based on the SPSS output in Figure 2, it was apparent that the nods had been spread above and below 0 randomly. At the same time, the nods did not form any waving pattern. Thereby, it could be concluded that heteroscedasticity did not take place.

\section{Multiple linear regression analysis}

In order to analyse the influence of learning motivation $\left(\mathrm{X}_{1}\right)$ and self-regulated learning $\left(\mathrm{X}_{2}\right)$ on Mathematics learning outcome (Y) from Grade XII Natural Science 1 students on "Derivative" materials from Trigonometry Functions, multiple linear regression was conducted by using SPSS Version 22 software. The equation model that had been used in the study was as follows:

$$
\hat{Y}=a+b_{1} X_{1}+b_{2} X_{2}
$$

Then, the results of the multiple linear regression analysis were presented in Table 14. Based on the results in Table 14, it was found that significance value (sig.) of learning motivation and selfregulated learning had been 0.001 . Since this value had been lower than 0.050 , it could be concluded that $\mathrm{H}_{0}$ had been rejected and $\mathrm{H}_{1}$ had been accepted. In other words, learning motivation and selfregulated learning had influence on Mathematics learning outcome of Grade XII Natural Science 1 students in a state Islamic senior high school in South Kalimantan during Covid-19 pandemics. In addition, the following multiple regression model was also attained:

$$
\hat{Y}=13,557+0.435 X_{1}+0.395 X_{2}+\varepsilon
$$


Jurnal Riset Pendidikan Matematika, 8 (2), 2021 - 161

Analisa Fitria, Baiti Najihah, Muhammad Amin Paris, Muh. Fajaruddin Atsnan, Maisea Ledua Nareki

Table 14. Multiple linear regression analysis

\begin{tabular}{|c|c|c|c|c|c|}
\hline \multicolumn{6}{|c|}{ Coefficients $^{\mathrm{a}}$} \\
\hline \multirow[t]{2}{*}{ Model } & \multicolumn{2}{|c|}{ Unstandardized Coefficients } & $\begin{array}{l}\text { Standardized } \\
\text { Coefficients }\end{array}$ & $t$ & Sig. \\
\hline & $B$ & Std. Error & Beta & & \\
\hline (Constant) & 13.557 & 4.681 & & 2.896 & 0.009 \\
\hline 1 Learning Motivation & 0.453 & 0.117 & 0.506 & 3.881 & 0.001 \\
\hline $\begin{array}{l}\text { Self-Regulated } \\
\text { Learning }\end{array}$ & 0.395 & 0.107 & 0.481 & 3.691 & 0.001 \\
\hline
\end{tabular}

The implications of the above model were as follows:

- The constant 13.557 showed if learning motivation $\left(\mathrm{X}_{1}\right)$ and self-regulated learning $\left(\mathrm{X}_{2}\right)$ were absent then Mathematics learning outcome would have been 13.557.

- The coefficient of regression for learning motivation $\left(X_{1}\right)$ was 0.453 , meaning that every $1 \%$ increase in the students' learning motivation $\left(\mathrm{X}_{1}\right)$ would result in 0.453 increase on Mathematics learning outcome $(\mathrm{Y})$ under the assumption that the other variable is constant.

- The coefficient of regression for self-regulated learning $\left(\mathrm{X}_{2}\right)$ was 0.395 , meaning that every $1 \%$ increase in the students' self-regulated learning $\left(\mathrm{X}_{2}\right)$ would result in 0.453 increase on Mathematics learning outcome under the assumption that the other variable is constant.

- The standard error 4.681 meant that all variables that have been calculated using SPSS had error level 4.681.

Based on the explanation of the multiple linear regression, it was clear that both learning motivation and self-regulated learning had positive value. In other words, it could be concluded that Mathematics learning outcome had improved because of the independent variables.

\section{Correlation analysis $(R)$ and coefficient of determination $\left(R^{2}\right)$}

The correlation analysis was conducted in order to identify the strength of the relationship between learning motivation $\left(\mathrm{X}_{1}\right)$ and self-regulated learning $\left(\mathrm{X}_{2}\right)$ during Covid-19 pandemic on Mathematics learning outcome $(\mathrm{Y})$ simultaneously. On the contrary, the coefficient of determination was conducted in order to identify the contribution of learning motivation $\left(\mathrm{X}_{1}\right)$ and self-regulated learning $\left(\mathrm{X}_{2}\right)$ on the fluctuation of Mathematics learning outcome. The results of correlation analysis and coefficient of determination were provided in Table 15.

Table 15. Correlation analysis and coefficient of determination

\begin{tabular}{ccccc}
\hline \multicolumn{4}{c}{ Model Summary } \\
\hline Model & $R$ & $R$ Square & $\begin{array}{c}\text { Adjusted } R \\
\text { Square }\end{array}$ & $\begin{array}{c}\text { Std. Error of the } \\
\text { Estimate }\end{array}$ \\
\hline 1 & $0.953^{\text {a }}$ & 0.909 & 0.900 & 2.290 \\
a. Predictors: (Constant), Self-Regulated Learning, Learning Motivation & & \\
\hline
\end{tabular}

Based on the results in Table 15 above, R-value was 0.953 . This $\mathrm{R}$-value showed that there had been very strong relationship between learning motivation and self-regulated learning during Covid-19 pandemic on Mathematics learning outcome. On the contrary, the results in Table 15 above also showed that $R$-square had been 0.909 . This value emphasized that the contribution of learning motivation and self-regulated learning during Covid-19 pandemic toward Mathematics learning outcome had been $90.90 \%$ while the remaining contribution was made by other variables.

\section{$t$-test}

$t$-test was conducted in order to identify whether learning motivation and self-regulated learning had partially significant influence on Mathematics learning outcome or not. The results of the t-test were provided in Table 16. 
Jurnal Riset Pendidikan Matematika, 8 (2), 2021 - 162

Analisa Fitria, Baiti Najihah, Muhammad Amin Paris, Muh. Fajaruddin Atsnan, Maisea Ledua Nareki

Table 16. $t$-test

\begin{tabular}{|c|c|c|c|c|c|}
\hline \multicolumn{6}{|c|}{ Coefficients $^{\mathbf{a}}$} \\
\hline \multirow[t]{2}{*}{ Model } & Unstandardized & Coefficients & $\begin{array}{c}\text { Standardized } \\
\text { Coefficients }\end{array}$ & $t$ & Sig. \\
\hline & $B$ & Std. Error & Beta & & \\
\hline (Constant) & 13.557 & 4.681 & & 2.896 & 0.009 \\
\hline${ }_{1}$ Learning Motivation & 0.453 & 0.117 & 0.506 & 3.881 & 0.001 \\
\hline $\begin{array}{l}\text { Self-Regulated } \\
\text { Learning } \\
\text { a. Dependent Variable: Mathematics Lea }\end{array}$ & outcome & 0.107 & 0.481 & 3.691 & 0.001 \\
\hline
\end{tabular}

Based on the results in Table 16, $\mathrm{t}_{\text {count }}$ value of learning motivation was 3.881 while $\mathrm{t}_{\text {count }}$ value of self-regulated learning was 3.691 with significance rate 0.001 . In the meantime, the $t_{\text {table }}$ value with degree of freedom $(d f)=n-2=24-2=22$ and $\alpha=5 \%$ is 2.074 . Since $\mathrm{t}_{\text {count }}$ value of learning motivation had been higher than $t_{\text {table }}$ value, it could be concluded that learning motivation had partially significant influence on Mathematics learning outcome during Covid-19 pandemic. At the same time, since tcount value of self-regulated learning had been higher than ttable value, it could also be concluded that self-regulated learning had partially significant influence on Mathematics learning outcome during Covid-19 pandemic.

\section{$F$-test}

In the study, $F$-test was conducted in order to identify the significant influence of learning motivation and self-regulated learning on Mathematics learning outcome during Covid-19 pandemics. The hypotheses that had been proposed with regards to the test were as follows: 1) Null Hypothesis $\left(H_{0}\right)$ : Learning motivation and self-regulated learning during Covid-19 pandemic do not influence Mathematics learning outcome of Grade XII Natural Science 1 students from a state Islamic senior high school in South Kalimantan, Indonesia; and 2) Alternate Hypothesis $\left(H_{0}\right)$ : Learning motivation and selfregulated learning during Covid-19 pandemic influence Mathematics learning outcome of Grade XII Natural Science 1 students from a state Islamic senior high school in South Kalimantan, Indonesia. The results of F-test were presented in Table 17.

Table 17. $F$-test

\begin{tabular}{|c|c|c|c|c|c|c|}
\hline \multicolumn{7}{|c|}{$\mathrm{ANOVA}^{\mathbf{a}}$} \\
\hline & & Sum of Squares & $d f$ & Mean Square & $F$ & Sig. \\
\hline \multirow{3}{*}{1} & Regression & 1100.518 & 2 & 550.259 & 104.948 & $0.000^{\mathrm{b}}$ \\
\hline & Residual & 110.107 & 21 & 5.243 & & \\
\hline & Total & 1210.625 & 23 & & & \\
\hline \multicolumn{7}{|c|}{ a. Dependent Variable: Mathematics Learning outcome } \\
\hline \multicolumn{7}{|c|}{ b. Predictors: (Constant), Self-Regulated Learning, Learning Motivation } \\
\hline
\end{tabular}

Based on the results in Table 17, it was clear that $F_{\text {count }}$ had been 104,948. On the contrary, the

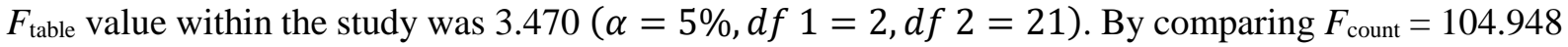
and $F_{\text {table }}=3.470$, it was apparent that $\mathrm{F}_{\text {count }}$ had been higher than $F_{\text {table }}(104.948>3.470)$. Therefore, it could be concluded that $H_{0}$ had been rejected and $H_{l}$ had been accepted. In other words, it could be concluded that learning motivation and self-regulated learning had during Covid-19 pandemic had influence on Mathematics learning outcome of Grade XII Natural Science 1 from a state Islamic senior high school in South Kalimantan on "Derivative" materials from Trigonometry Functions.

\section{Discussions}

Referring to the results of the study, which conclude that learning motivation and self-regulated learning have influence on students' outcome on learning derivative of Trigonometry Functions, the researchers would like to draw several implications. First, it is found that the influence of learning motivation during Covid-19 pandemic on Mathematics learning outcome is $47.57 \%$ with "Very Good" interpretation. In the meantime, the learning outcome are various with the modus on the "Moderate" 
qualification or category. These findings show that the higher the learning motivation is the higher the Mathematics learning outcome will be (Jemudin et al., 2019, p.7; Simatupang, 2019, p.12). Inherent motivation is a motivation that comes from within the individual itself (Riswanto \& Ariyani, 2017, p.44). Moreover, the pandemic demands motivation from students who are getting bigger.

At the same time, these findings also show significant relationship between learning motivation and Mathematics learning outcome (Jatmiko, 2015, p.208; Sumantri \& Wardhani, 2017, p.122). In short, learning motivation has influence on the improvement of students' learning outcome (Tambunan, 2020, p.113). Therefore, it depends on how the Mathematics teacher builds and develops the learning motivation among the students during Covid-19 pandemic. If mathematics teacher is able to develop the students' learning motivation, then the students' enthusiasm, interest and encouragement in learning will develop and the development will result in good learning outcome (Sardiman, 2011, p.87).

Second, it is found that the influence of self-regulated learning during Covid-19 pandemic on Mathematics learning outcome is $44.63 \%$ with "Moderately Independent" interpretation. Looking at the interpretation, it can be concluded that the higher the self-regulated learning is, the higher the Mathematics learning outcome will be (Simatupang, 2019, p.12). When the students have increasingly self-regulated learning, their learning outcome will improve and their understanding toward a concept will be better (Putri et al., 2020, p.198). In the context of Mathematics learning process, there is a proportional relationship between self-regulated learning and students' understanding capacity (Lestari, Aisah \& Nurafifah, 2020, p.5). Furthermore, self-regulated learning of the students also impacts the awareness and the responsibility of a student in a learning process (Jatisunda, Nahdi \& Suciawati, 2020, p.89). A student with high sense of self-regulated learning, despite the online learning system, will always take full responsibility during the learning process. Therefore, it will depend on the teacher to develop the intended self-regulated learning certainly by not giving more Mathematics assignments that demand more self-regulated learning among the students.

Third, it is found that learning motivation and self-regulated learning during Covid-19 pandemic have significant influence on Mathematics learning students. This finding implies that despite Covid-19 pandemic learning motivation and self-regulated learning have influence on Mathematics learning outcome. The statement can be confirmed from each aspect, which has been linear with the Mathematics learning outcome in this study.

It turns out that the pandemic has changed habits related to learning motivation and learning independence more or less. Based on the results of the study, it appears that there is a change in indicators of learning motivation, where perseverance in facing math tasks, tenacity in facing math difficulties, and the desire to succeed in learning mathematics are reduced. Meanwhile, for the independence of learning mathematics, all indicators have changed, where all of them are less than $50 \%$ of students who have the initiative to plan mathematics learning strategies, organize and direct themselves to learn mathematics, have responsibility for themselves when learning mathematics, and the most visible change is dependence on others to complete tasks is getting smaller. This confirms several previous studies which say that the Covid-19 pandemic with its online learning system has had an impact on students' mathematics learning motivation (Siregar \& Manurung, 2021; Jatisunda, Nahdi, \& Suciawati, 2020, p.85).

\section{CONCLUSION}

Based on the results of the study, the researchers would like to draw several conclusions. First, the students' motivation during Covid-19 pandemic in learning Derivative of Trigonometry Function is $47.57 \%$. Second, the students' self-regulated learning during Covid-19 pandemic in learning Derivative of Trigonometry Function is $44.63 \%$. Third, both learning motivation and self-regulated learning during Covid-19 pandemic have significant influence on Mathematics learning outcome.

Despite those conclusions, it turns out that both learning motivation and self-regulated learning influence Mathematics learning outcome before the outbreak of Covid-19 pandemic. Recalling the positive impact of the two affective aspects toward the cognitive aspect of the students in the form of Mathematics learning outcome, it is expected that Mathematics teachers motivate the students to be selfregulated in learning Mathematics instead of teaching Mathematics online by giving more assignments to the students since this action will only make the students lazy. 


\section{REFERENCES}

Aguilera-Hermida, A. P. (2020). College students' use and acceptance of emergency online learning due to COVID-19. International Journal of Educational Research Open, 1, 100011. https://doi.org/10.1016/j.ijedro.2020.100011

Ambiyar, A., Aziz, I., \& Melisa, M. (2020). Perbedaan kemandirian belajar siswa pada masa pandemi di SMAN 1 Lembah Melintang dan SMAN 1 Lembah Gumanti [Differences in student learning independence during the pandemic at SMAN 1 Lembah Transverse and SMAN 1 Lembah Gumanti]. Jurnal Cendekia: Jurnal Pendidikan Matematika, 04(02), 1246-1258. https://doi.org/10.31004/cendekia.v4i2.367

Arikunto, S. (2010). Prosedur penelitian suatu pendekatan praktek [Research procedures a practical approach]. Jakarta, Indonesia: Rineka Cipta

Atmojo, S. E., Muhtarom, T., \& Lukitoaji, B. D. (2020). The level of self-regulated learning and selfawareness in science learning in the covid-19 pandemic era. Jurnal Pendidikan IPA Indonesia, 9(4), 512-520. https://doi.org/10.15294/jpii.v9i4.25544

Azka, R., \& Santoso, R. H. (2015). Pengembangan perangkat pembelajaran kalkulus untuk mencapai ketuntasan dan kemandirian belajar siswa [Development of calculus learning tools to achieve mastery and independent learning of students]. Jurnal Riset Pendidikan Matematika, 2(1), 7891. http://dx.doi.org/10.21831/jrpm.v2i1.7152

Cahyani, A., Listiana, I. D., \& Larasati, S. P. D. (2020). Motivasi belajar siswa SMA pada pembelajaran daring di masa pandemi Covid-19 [High school students' learning motivation in online learning during the Covid-19 pandemic]. IQ (Ilmu Al-Qur'an): Jurnal Pendidikan Islam, 3(01), 123140. https://doi.org/10.37542/iq.v3i01.57

Fane, A., \& Sugito, S. (2019). Pengaruh keterlibatan orang tua, perilaku guru, dan motivasi belajar terhadap prestasi belajar matematika siswa [The influence of parental involvement, teacher behavior, and learning motivation on students' mathematics learning achievement]. Jurnal Riset Pendidikan Matematika, 6(1), 53-61. http://dx.doi.org/10.21831/jrpm.v6i1.15246

Fauzi, A., \& Widjajanti, D. B. (2018). Self-regulated learning: the effect on student's mathematics achievement. Journal of Physics: Conference Series, 1097 (2018) 012139. https://doi.org/10.1088/1742-6596/1097/1/012139

Gazali, R. Y., \& Atsnan, M. F. (2017). Peningkatan motivasi dan minat belajar matematika siswa melalui pendekatan kontekstual dalam pembelajaran matematika yang bermakna [Increasing students' motivation and interest in learning mathematics through a contextual approach in meaningful mathematics learning]. Pythagoras: Jurnal Pendidikan Matematika, 12(2), 123134. https://journal.uny.ac.id/index.php/pythagoras/article/view/15987

Jatmiko, J. (2015). Hubungan motivasi belajar dengan hasil belajar matematika siswa kelas X SMK Nahdhatul Ulama Pace Nganjuk [The relationship between learning motivation and mathematics learning outcomes for class X students of SMK Nahdhatul Ulama Pace Nganjuk]. Jurnal Math Educator Nusantara, 1(2), 205-213. https://ojs.unpkediri.ac.id/index.php/matematika/article/view/237

Jatisunda, Mohamad G., Nahdi, Dede S., \& Suciawati, V. (2020). Virtual class during Covid 19: A selfregulated learning study of mathematics pre-service teacher. International Journal on Emerging Mathematics Education (IJEME), 4(2), 81-94. https://doi.org/10.12928/ijeme.v4i2.16671

Jemudin, F. D. E., Makur, A. P., \& Ali, F. A. (2019). Hubungan sikap belajar dan motivasi belajar terhadap prestasi belajar matematika siswa SMPN 6 Langke Rembong [The relationship between learning attitudes and learning motivation on mathematics learning achievement of SMPN 6 Langke Rembong students]. Journal of Honai Math, 2(1), 1-11. https://doi.org/10.30862/jhm.v2i1.53

Kurniawan, D., \& Wustqa, D. U. (2014). Pengaruh perhatian orangtua, motivasi belajar, dan lingkungan sosial terhadap prestasi belajar matematika siswa SMP [The influence of parental attention, 
learning motivation, and social environment on mathematics learning achievement of junior high school students]. Jurnal Riset Pendidikan Matematika, 1(2), 176-187. http://dx.doi.org/10.21831/jrpm.v1i2.2674

Kurniyawati, Y., Mahmudi, A., \& Wahyuningrum, E. (2019). Efektivitas problem-based learning ditinjau dari keterampilan pemecahan masalah dan kemandirian belajar matematis [The effectiveness of problem-based learning in terms of problem solving skills and independent learning of mathematics]. Jurnal Riset Pendidikan Matematika, 6(1), 118-129. http://dx.doi.org/10.21831/jrpm.v6i1.26985

Lestari, K. E., \& Yudhanegara, M. R. (2017). Penelitian pendidikan matematika [Mathematics education research]. Bandung, Indonesia: PT. Refika Aditama

Lestari, W. D., Aisah, L. S., \& Nurafifah, L. (2020). What is the relationship between self-regulated learning and students' mathematical understanding in online lectures during the covid-19 pandemic?. Journal of Physics: Conference Series, $2^{\text {nd }}$ ISSAME 2020. https://doi.org/10.31004/basicedu.v4i3.422

Mou, T-Y. (2021). Online learning in the time of the COVID-19 crisis: implications for the selfregulated learning of university design students. Active Learning in Higher Education, 1-21. https://doi.org/10.1177\%2F14697874211051226

Nurhayati, F. E., \& Purwanto, S. E. (2021). Analysis of the mathematics learning motivation of class xi IPA students during the covid-19 pandemic. Edumatica: Jurnal Pendidikan Matematika, 11(01), 93-98. https://doi.org/10.22437/edumatica.v11i01.12440

Nuriyatin, S., \& Hartono, H. (2016). Pengembangan pembelajaran penemuan terbimbing untuk meningkatkan berpikir kritis dan motivasi belajar geometri di SMP [Development of guided discovery learning to improve critical thinking and motivation to learn geometry in junior high school]. Pythagoras: Jurnal Pendidikan Matematika, 11(2), 207-218. http://dx.doi.org/10.21831/pg.v11i2.10656

Putri, H. E., Muqodas, I., Sasqia, A. S., Abdulloh, A., \& Yuliyanto, A. (2020). Increasing self regulated learning of elementary school students through the concrete-pictorial-abstract approach during the COVID-19 pandemic. Premiere Educandum: Jurnal Pendidikan Dasar dan Pembelajaran, 10(2), 187-202. http://doi.org/10.25273/pe.v10i2.7534

Qohar, A., \& Sumarmo, U. (2013). Improving mathematical communication ability and self regulation learning of yunior high students by using reciprocal teaching. Journal on Mathematics Education, 4(1), 59-74. https://doi.org/10.22342/jme.4.1.562.59-74

Ridwan, R., \& Sunarto, S. (2009). Pengantar statistika [Introduction to statistics]. Bandung, Indonesia: Alfabeta.

Riswanto, A., \& Aryani, S. (2017). Learning motivation and student achievement: description analysis and relationships both. COUNS-EDU. The International Journal of Counseling and Education, 2(1), 42-47. http://dx.doi.org/10.23916/002017026010

Sardiman, A. M. (2011). Interaksi dan motivasi belajar mengajar [Teaching and learning interaction and motivation]. Jakarta, Indonesia: Raja Grafindo Persada.

Simatupang, H. (2019). Strategi belajar mengajar abad ke-21 [21st century teaching and learning strategies]. Surabaya, Indonesia: CV. Cipta Media Edukasi.

Siregar, N., \& Manurung, S. (2021). Analysis of the learning motivation of students in mathematics education online learning. Journal of Physics: Conference Series, 1819 (2021) 012069. https://doi.org/10.1088/1742-6596\%2F1819\%2F1\%2F012069

Sugiyono. (2016). Metode penelitian pendidikan: pendekatan kuantitatif, kualitatif, dan $R \& D$ [Educational research methods: quantitative, qualitative, and R\&D approaches]. Bandung, Indonesia: Alfabeta. 
Jurnal Riset Pendidikan Matematika, 8 (2), 2021 - 166

Analisa Fitria, Baiti Najihah, Muhammad Amin Paris, Muh. Fajaruddin Atsnan, Maisea Ledua Nareki

Sumantri, M. S., \& Whardani, P. A. (2017). Relationship between motivation to achieve and professional competence in the performance of elementary school teachers. International Education Studies, 10(7), 118-125. https://doi.org/10.5539/ies.v11n4p144

Tambunan, H. (2020). Kinerja guru matematika SMP dalam membangun minat dan motivasi belajar siswa [Junior high school mathematics teacher performance in building student interest and motivation]. Jurnal Riset Pendidikan Matematika, 7(1), 108-117. https://journal.uny.ac.id/index.php/jrpm/article/view/19384

Wahyuningsih, D. D. (2020). Panduan untuk konselor teknik self management dalam bingkai konseling cognitive behavior untuk meningkatkan kemandirian belajar siswa SMP [A guide for counselors on self-management techniques in the framework of cognitive behavior counseling to increase the learning independence of junior high school students]. Semarang, Indonesia: CV. Sarnu Untung

Warmi, A., Adirakasiwi, A. G., \& Santoso, E. (2020). Motivasi dan kemandirian belajar siswa pada mata pelajaran matematika di masa pandemi covid-19 (studi pada siswa kelas VII SMPN 3 karawang tahun pelajaran 2019-2020) [Student motivation and learning independence in mathematics during the covid-19 pandemic (study of class VII students of SMPN 3 Karawang in the 2019-2020 school year)]. Jurnal Education and Development, 8(3), 197-202. https://journal.ipts.ac.id/index.php/ED/article/view/1937

Wijaya, T. T., Ying, Z., \& Suan, L. (2020). Gender and self-regulated learning during COVID-19 pandemic in Indonesia. Jurnal Basicedu (Research \& Learning in Elementary Education), 4(3), 725-732. https://doi.org/10.31004/basicedu.v4i3.422 